\title{
PENGARUH LINGKUNGAN KERJA DAN DISIPLIN KERJA TERHADAP KEPUASAN KERJA GURU SEKOLAH MENENGAH KEJURUAN (SMK) SWASTA SEKECAMATAN PONDOK AREN
}

\author{
DEWI PURNAMA SARI \\ Program Studi Matematika, FMIPA - UNPAM \\ dosen01569@unpam.ac.id
}

\begin{abstract}
"Influence of Pengaruh Lingkungan Kerja dan Disiplin Kerja Terhadap Kepuasan kerja Guru SMK di Kecamatan Pondok Aren”. This study intends to determine, assess and analyze the influence of the working environment and discipline, work on job satisfaction of teachers.

Hypotheses tested were: (1) The effect of the work environment on job satisfaction of teachers, (2) Effect of labor discipline on job satisfaction of teachers, (3) Effect of the working environment to work discipline teacher.
\end{abstract}

This research was conducted using a survey method, the target population of 135 people. Furthermore, the population is first homogenized so that the samples taken are as many as 101 teachers. In determining the authors use the technique of random sampling (simple random sampling). To test a sample instrument used by 30 teachers, who were taken outside the study sample. A trial was made to measure the degree of validity of the instrument is calculated using the formula Iteman and measure the degree of reliability of the instrument is calculated using Cronbach alpha formula to test the validity of the test citeria is $r_{\text {hitung }}>r_{\text {kritis }}$ at $\alpha(0,05)=0,361$, then the instrument is said to be valid. As per the calculation result of the trial showed that ritung instrument that is greater than $r_{k r i t i s}$ so that the instrument be valid, unless the item question/statement number 8 and 17 on the variables $X_{1}$, item number 1,8 and 17 for the variables $X_{2}$, and item numbers 8 and 30 for variables $X_{3}$, so that these items can not bu used in future studies.

While the reliability test criteria used are Alpha Cronbach values obtained in rhitung > $r_{\text {tabel }}$ the instrument said to be reliable. Corresponding reliability test results can be seen that the value obtained for Alpha Cronbach Lingkungan Kerja variable rhitung $=$ 0,822, untuk variabel Disiplin Kerja $r_{h i t u n g}=0,714$, dan untuk variabel Kepuasan Kerja Guru $r_{\text {hitung }}=0,649$. Based on the test results it can be concluded that the items on all the variables declared reliable.

For the results of the study can be summarized as follows: First there is the influence of Teachers Working Environment (X1) on Teacher Job Satisfaction (X3) with equation X3 $=8.49+0,95 X 2$. With a correlation coefficient $r 13=0.351$ and p32 pathways coefficient $=0.43$. Second: there is a positive effect of Discipline Work (X2) on Teacher 
Job Satisfaction (X3) with a regression equation $X 3=45.92+0,59 X 1$. With a correlation coefficient of 0.351 , and the $p 31$ pathway coefficient $=0.08$. Third: there is a positive effect of Teachers Working Environment (X1) of the Work Discipline Teachers (X2) with a regression equation $X 2=37.42+0,64 X 1$ with correlation coefficients of 0.514 and 21 pathways coefficient $=0.51$.

Thus it can be said that the work environment and work discipline alone or together can provide a very significant contribution to improving job satisfaction of teachers, so it is expected that the results of this study can be used as a reference in a school building in accordance with national education goals.

Keywords: Education, Teachers Working.

\begin{abstract}
ABSTRAK
"Pengaruh Lingkungan Kerja dan Disiplin Kerja Terhadap Kepuasan kerja Guru SMK di Kecamatan Pondok Aren" . Penelitian ini bermaksud untuk mengetahui, mengkaji dan menganalisis adanya pengaruh lingkungan kerja dan disiplin kerja terhadap kepuasan kerja guru.
\end{abstract}

Hipotesis yang di uji adalah : (1) Pengaruh lingkungan kerja terhadap kepuasan kerja guru, (2) Pengaruh disiplin kerja terhadap kepuasan kerja guru, (3) Pengaruh lingkungan kerja terhadap disiplin kerja guru.

Penelitian ini dilakasanakan dengan menggunakan metode survey. Populasi targer sebanyak 135 orang. Selanjutnya populasi tersebut dihomogenkan terlebih dahulu sehingga sampel yang diambil adalah guru sebanyak 101 orang. Dalam menentukan sampel penulis menggunakan teknis acak sederhana (simple random sampling). Untuk uji coba instrumen seampel yang digunakan sebanyak 30 orang guru, yang diambil di luar sampel penelitian. Uji coba dilakukan untuk mengukur tingkat validitas instrumen yang dihitung dengan menggunakan itemen dan mengukur tingkat reliabilitas instrumen yang dihitung menggunakan itemen. Untuk uji validitas kriteria pengujian adalah $\mathbf{r}_{\text {hitung }}$ $>\mathrm{r}_{\text {kritis }}$ pada $\alpha(0,05)=0,361$ maka intrumen dikatakan valid. Sesuai perhitungan hasil uji coba instrumen menunjukan bahwa $r_{\text {hitung }}$ yang diperoleh lebih besar dari $\mathrm{r}_{\text {kritis }}$ sehingga instrumen dikatakan valid, kecuali pada item pernyataan nomor 8 dan 17 pada variabel $X_{1}$, item nomor 1,8 dan 17 pada variabel $X_{2}$ dan item nomor 8 dan 30 pada variabel $\mathrm{X}_{3}$, sehingga item-item tersebut tidak dapat digunakan dalam penelitian selanjutnya.

Sedangkan uji coba reliabilitas kriteria yang digunakan nilai Alpha Cronbach yang diperoleh pada $r_{\text {hitung }}>r_{\text {tabel }}$ maka instrumen dikatakan reliabel. Sesuai hasil uji reliabilitas dapat diketahui bahwa nilai Alpha Cronbach yang diperoleh untuk variabel Lingkungan Kerja $\mathbf{r}_{\text {hitung }}=0,822$, untuk variabel Disiplin Kerja $\mathbf{r}_{\text {hitung }}=0,714$, dan untuk variabel Kepuasan Kerja Guru $r_{\text {hitung }}=0,649$. berdasarkan hasil pengujian tersebut maka dapat disimpulkan bahwa item-item pada semua variabel dinyatakan reliabel.

Untuk hasil penelitian dapat disimpulkan sebagai berikut : Pertama terdapat pengaruh Lingkungan Kerja Guru $\left(\mathrm{X}_{1}\right)$ terhadap Kepuasan Kerja Guru $\left(\mathrm{X}_{3}\right)$ dengan persamaan $\mathrm{X}_{3}=8,49+0,95 \mathrm{X}_{2}$. Dengan koefisien korelasi $\mathrm{r}_{13}=0,351$ serta koefisien jalur $\mathrm{p}_{32}=0,43$. Kedua : terdapat pengaruh positif Disiplin Kerja $\left(\mathrm{X}_{2}\right)$ terhadap 
Kepuasan Kerja Guru $\left(\mathrm{X}_{3}\right)$ dengan persamaan regresi $\mathrm{X}_{3}=45,92+0,59 \mathrm{X}_{1}$. Dengan koefisien korelasi 0,351 , serta koefisien jalur $\mathrm{p}_{31}=0,08$. Ketiga : terdapat pengaruh positif Lingkungan Kerja Guru $\left(\mathrm{X}_{1}\right)$ terhadap Disiplin Kerja Guru $\left(\mathrm{X}_{2}\right)$ dengan persamaan regresi $\mathrm{X}_{2}=37,42+0,64 \mathrm{X}_{1}$ dengan koefisien korelasi 0,514 serta koefisien jalur $\mathrm{p}_{21}=0,51$.

Dengan demikian maka dapat dikatakan bahwa antara lingkungan kerja dan disiplin kerja secara sendiri maupun bersama-sama dapat memberi sumbangan yang sangat berarti dalam upaya meningkatkan kepuasan kerja guru, sehingga diharapkan agar hasil penelitian ini dapat dijadikan acuan dalam membangun sekolah sesuai dengan tujuan pendidikan nasional.

\section{Kata kunci: Pendidikan, Kerja Guru.}

\section{PENDAHULUAN}

\subsection{Latar Belakang Masalah}

Kepuasan kerja guru akan membawa dampak bagi guru yang bersangkutan tempat ia bekerja. Bagi guru, tingkat kepuasan kerja yang tinggi dapat memberikan keuntungan tersendiri, seperti meningkatkan gaji, memperluas kesempatan untuk dipromosikan, menurunnya kemungkinan untuk didemosikan, serta membuat ia semakin ahli dan berpengalaman dalam bidang pekerjaannya. Sebaliknya, tingkat kepuasan kerja guru yang rendah menunjukkan bahwa guru tersebut sebenarnya tidak kompeten dalam pekerjaannya, akibatnya ia sukar untuk dipromosikan ke jenjang pekerjaan yang tingkatannya lebih tinggi, memperbesar kemungkinan untuk didemosikan, dan pada akhirnya dapat juga menyebabkan guru tersebut mengalami pemutusan hubungan kerja.

Kualitas sumber daya manusia sangat menentukan keberhasilan suatu organisasi, demikian juga dengan organisasi di bidang pendidikan. Faktor utama yang menentukan tercapaianya tujuan organisasi sangat ditentukan oleh sumber daya manusia yang memiliki prestasi. Oleh karena itu untuk menghasilkan prestasi, organisasi harus dimulai dari perbaikan kepuasan kerja personal dan anggota organisasi.

Faktor personal meliputi ciri sifat kepribadian (personality trait), senioritas, masa kerja, kemampuan ataupun keterampilan yang berkaitan dengan bidang pekerjaan, dan kepuasan hidup. Untuk faktor personal, faktor yang juga penting dalam mempengaruhi kepuasan kerja adalah faktor status dan masa kerja. Pada 
umumnya, orang yang telah memiliki status pekerjaan yang lebih tinggi biasanya telah menunjukkan kepuasan kerja yang baik. Status pekerjaan tersebut dapat memberikannya kesempatan untuk memperoleh masa kerja yang lebih baik, sehingga kesempatannya untuk semakin menunjukkan kepuasan kerja juga semakin besar.

\subsection{Rumusan Masalah}

Bertolak dari identifikasi masalah dan pembatasan masalah di atas, maka dapat dirumuskan masalah dalam penelitian ini sebagai berikut :

1. Apakah terdapat pengaruh lingkungan kerja terhadap kepuasan kerja guru SMK di Kecamatan Pondok Aren?

2. Apakah terdapat pengaruh disiplin kerja terhadap kepuasan kerja guru SMK di Kecamatan Pondok Aren?

3. Apakah terdapat pengaruh lingkungan kerja terhadap disiplin kerja pada SMK di Kecamatan Pondok Aren?

\subsection{Tujuan Penelitian}

Secara umum penelitian ini bertujuan untuk mendapatkan data empiric, fakta dan informasi yang shahih (valid) dan benar serta dapat dipercaya (reliabel) tentang pengaruh lingkungan kerja dan disiplin kerja terhadap kepuasan kerja guru. Di samping itu, penelitian ini secara lebih spesifik bertujuan untuk mengetahui hal-hal sebagai berikut :

1. Pengaruh lingkungan kerja terhadap kepuasan kerja guru di SMK wilayah kecamatan Pondok Aren.

2. Pengaruh di disiplin kerja terhadap kepuasan kerja guru di SMK wilayah kecamatan Pondok Aren. 
3. Pengaruh lingkungan kerja terhadap disiplin kerja guru di wilayah SMK kecamatan Pondok Aren.

\subsection{Manfaat Penelitian}

Hasil penelitian ini diharapkan dapat bermanfaat baik secara teoritis maupun secara praktis.

1. Secara Teoritis

Dari hasil penelitian ilmiah ini diharapkan para akademisi dapat melakukan pengkajian yang lebih mendalam, dapat mengembangkan ilmu dan konsepkonsep yang berhubungan dengan disiplin guru, lingkungan kerja guru, dan Kepuasan kerja guru serta mengimplementasikannya di dalam masyarakat.

\section{METODOLOGI PENELITIAN}

\subsection{Desain Penelitian}

Metode penelitian ini adalah metode survey kausal dengan teknik analisis jalur (path analysis) yang menguji pengaruh langsung dan tidak langsung dari setiap variabel.

Variabel Eksogen

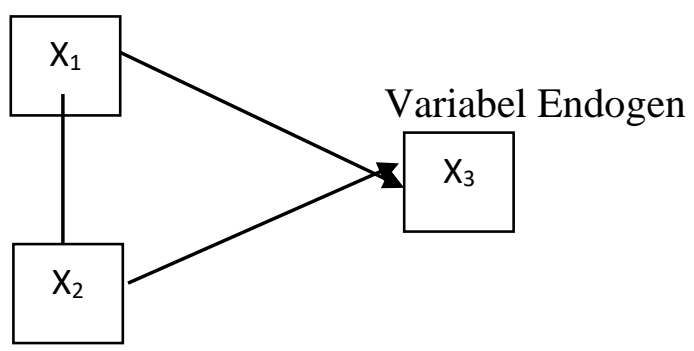

Keterangan : $\mathrm{X}_{1}=$ Lingkungan Kerja Guru

$\mathrm{X}_{2}=$ Disiplin Kerja Guru

$\mathrm{X}_{3}=$ Kepuasan Kerja Guru 


\subsection{Populasi}

\begin{tabular}{|l|l|l|}
\hline No. & Nama Sekolah & Jumlah Guru \\
\hline 1 & SMK KEBANGSAAN & 36 \\
\hline 2 & SMK YAPIA & 34 \\
\hline 3 & SMK BINUSA & 35 \\
\hline 4 & SMK FADILAH & 30 \\
\hline TOTAL & & 135 \\
\hline
\end{tabular}

Sumber : SMK di Kecamatan Pondok Aren, November 2014

Menentukan besarnya sampel menggunakan rumus Slovin.

$$
\begin{aligned}
\mathrm{n} & =\frac{N}{1+N e^{2}} \\
& =\frac{135}{1+135(0,05)^{2}}=101
\end{aligned}
$$

Keterangan:

$$
\begin{aligned}
1 & =\text { konstanta } \\
n= & \text { ukuran sampel } \\
\mathrm{N}= & \text { ukuran populasi } \\
\mathrm{e}^{2}= & \text { kelonggaran ketidaktelitian karena kesalahan pengambilan sampel } \\
& \text { yang dapat ditolerir. }
\end{aligned}
$$

Dalam penelitian ini, peneliti menggunakan empat sekolah dengan populasi 135 guru, sampel 101 guru, dan uji coba 30 guru yang tidak termasuk sampel.

\subsection{Kajian Pustaka}

Kepuasan Kerja Guru 
Dalam penelitian ini kepuasan kerja adalah suatu sikap positif yang menyangkut penyesuaian diri para guru terhadap pekerjaannya. Jika guru merasa puas terhadap pekerjaannya, maka guru tersebut memiliki sikap positif dan bangga, serta menilai pekerjaannya tinggi, karena situasi dan kondisi kerja dapat memenuhi kebutuhan, keinginan, dan harapannya.

\section{Lingkungan Kerja Guru}

lingkungan kerja guru adalah kondisi dan hubungan kerja seorang guru secara individual dan kelompok yang meliputi : penerangan, pewarnaan, kebersihan, pertukaran udara, keamanan, kebisingan (suara), tata ruang ruang kerja dan peralatan kerja, serta hubungan kerja yang terdiri dari komunikasi, kerjasama, suasana kerja dan sikap.

\section{Disiplin Kerja Guru}

Disiplin kerja guru adalah ketaatan guru yang terbentuk melalui proses dari serangkaian perilaku yang menunjukkan keteraturan berdasarkan acuan nilai moral individu guru untuk memperoleh perubahan tingkah laku yang mencakup perubahan berfikir, memiliki tanggung jawab, dan tindakan yang sesuai dengan standar sosial.

\subsection{Metode Penentuan Sampel}

Sejalan dengan permasalahan yang diteliti dalam penelitian ini, yaitu Pengaruh Disiplin dan Lingkungan Kerja Terhadap Kepuasan kerja Guru Pada SMK di Kecamatan Pondok Aren, sehingga untuk menghindari adanya distorsi hasil penelitian, pengambilan sampel akan digunakan berdasarkan jumlah anggota populasinya, yaitu sebanyak 135 guru.

Hal tersebut sesuai sebagaimana yang disampaikan oleh Widodo bahwa penentuan metode pengambilan sampel tergantung pada besarnya jumlah populasi dan kesanggupan peneliti untuk menjangkaunya ( Widodo,2004:76). Sekiranya jumlah sampel terbatas, misalnya kurang dari 135 (seratus tiga puluh lima) dan peneliti memiliki kesanggupan untuk menjangkau secara keseluruhan, maka 
metode pengambilan yang digunakan adalah metode sensus atau metode sampel jenuh.

\subsection{Metode Pengolahan Data}

Dari data yang terkumpul dianalisis dengan menggunakan statistik deskriptif dan inferensial yang sering disebut statistik probabilitas. Dari statistik deskriptif untuk mengukur dan penyajian ukuran gejala terpusat yang terdiri dari skor minimum dan maksimum. Analisis statistik deskriptif dilakukan dengan mendeskripsikan semua data dari semua variabel dalam bentuk distribusi frekuensi, histigram, modus, median, dan validitas, reliabilitas, atau penyebaran rentang skor dan simpangan baku. Sedangkan analisis statistik inferensial adalah teknik statistik yang digunakan untuk menguji hipotesis yang akan memakai analisis jalur (path analisis).

Uji persyaratan analisis yang digunakan dalam penelitian ini terdiri dari :

1. Uji normalitas data

Uji ini dimaksudkan untuk menentukan normal atau tidaknya distribus data penelitian dengan menggunakan uji Liliefors (data dikatakan normal bila $\mathrm{L}_{\text {hitung }}$ $<\mathrm{L}_{\text {tabel }}$ diuji pada taraf signifikan $\alpha=0,05$.

2. Uji homogenitas data.

Uji ini dimaksudkan untuk menguji kesamaan dua buah varians populasi yang berdistribusi normal. Uji homogenitas data dengan menggunakan uji Bartlett. Data dikatakan homogen apabila $X_{\text {hitung }}<X_{\text {tabel }}$ diuji pada taraf signifikan $\alpha=0,05$.

3. Uji Linieritas Data dan Keberartian Regresi

Uji linieritas regresi dan keberartian regresi dari persamaan regresi linier sederhana antara $X_{1}$ dan $X_{3}, X_{2}$ dan $X_{3}$, serta $X_{1}$ dan $X_{2}$ digunakan analisis varians melalui tabel ANAVA. Dengan ketentuan apabila pada baris Tuna Cocok dihasilkan $\mathrm{F}_{\text {hitung }}<\mathrm{F}_{\text {tabel}}$, maka persamaan regresinya linier. Dan apabila 
pada baris regresi (b/a) dihasilkan $F_{\text {hitung }}>F_{\text {tabel, }}$ maka koefisien regresinya dikatakan berarti.

\section{HASIL DAN PEMBAHASAN}

\subsection{Definisi Konseptual dan Operasional Variabel}

Variabel penelitian perlu didefinisikan, baik secara konseptual maupun secara operasional dengan tujuan untuk menjelaskan makna variabel penelitian. Variabel penelitian terdiri dari satu variabel tidak bebas atau terikat dan dua variabel bebas. Untuk variabel tidak bebas atau terikat yaitu: Variabel Kepuasan kerja Guru $\left(\mathrm{X}_{3}\right)$, sedangkan untuk variabel bebas, terdiri dari : Variabel Lingkungan Kerja Guru $\left(\mathrm{X}_{1}\right)$, dan Variabel Disiplin Kerja Guru $\left(\mathrm{X}_{2}\right)$.

Definisi Konseptual dan Operasional variabel secara berturut-turut dapat diuraikan sebagai berikut :

\subsubsection{Variabel Kepuasan kerja Guru $\left(\mathrm{X}_{3}\right)$}

\subsubsection{Definisi Konseptual}

Kepuasan kerja adalah suatu sikap positif yang menyangkut penyesuaian diri para guru terhadap pekerjaanny. Jika guru merasa puas terhadap pekerjaannya, maka guru tersebut memiliki sikap positif dan bangga, serta menilai pekerjaannya tinggi, karena situasi dan kondisi kerja dapat memenuhi kebutuhan, keinginan, dan harapannya.

\subsubsection{Definisi Operasional}

Kepuasan kerja guru adalah skor yang diperoleh dari jawaban responden mengenai variabel Kepuasan Kerja Guru yang diukur melalui dimensi, pekerjaan itu sendiri dengan indikatornya, skor tersebut diperoleh dengan menggunakan skala Likert dengan 5 opsi jawaban yaitu, Sangat Setuju ( SS ), Setuju ( S ), Kurang Setuju ( KS ), Tidak Setuju ( TS ), dan Sangat Tidak Setuju ( STS ). 


\subsubsection{Variabel Lingkungan Kerja Guru ( $\left.\mathrm{X}_{1}\right)$}

\subsubsection{Definisi Konseptual}

Lingkungan kerja guru adalah kondisi dan hubungan kerja seorang guru secara individual dan kelompok yang meliputi : penerangan, pewarnaan, kebersihan, pertukaran udara, keamanan, kebisingan (suara), tata ruang ruang kerja dan peralatan kerja, serta hubungan kerja yang terdiri dari komunikasi, kerjasama, suasana kerja dan sikap.

\subsubsection{Definisi Operasional}

Lingkungan kerja guru adalah skor yang diperoleh dari jawaban responden mengenai variabel Lingkungan Kerja Guru yang diukur melalui dimensi, pekerjaan itu sendiri dengan indikatornya, skor tersebut diperoleh dengan menggunakan skala Likert dengan 5 opsi jawaban yaitu, Sangat Setuju ( SS ), Setuju ( S ), Kurang Setuju ( KS ), Tidak Setuju ( TS ), dan Sangat Tidak Setuju ( STS ).

\subsubsection{Variabel Disiplin Kerja Guru $\left(\mathbf{X}_{2}\right)$}

\subsubsection{Definisi Konseptual}

Disiplin kerja guru adalah ketaatan guru yang terbentuk melalui proses dari serangkaian perilaku yang menunjukkan keteraturan berdasarkan acuan nilai moral individu guru untuk memperoleh perubahan tingkah laku yang mencakup perubahan berfikir, memiliki tanggung jawab, dan tindakan yang sesuai dengan standar sosial.

\subsubsection{Definisi Operasional}

Disiplin kerja guru adalah skor yang diperoleh dari jawaban responden mengenai variabel Disiplin Kerja Guru yang diukur melalui dimensi, pekerjaan itu sendiri dengan indikatornya, skor tersebut diperoleh dengan menggunakan skala Likert dengan 5 opsi jawaban yaitu, Sangat Setuju ( SS ), Setuju ( S ), Kurang Setuju ( KS ), Tidak Setuju ( TS ), dan Sangat Tidak Setuju ( STS ). 


\subsection{Instrumen Penelitian}

Untuk memperoleh data empiris mengenai variabel yang diamati, dalam penelitian ini digunakan seperangkat instrumen berbentuk angket (kuesioner). Kuesioner digunakan untuk menghimpun informasi mengenai disiplin, lingkungan kerja dan Kepuasan kerja guru.

Konsepsi yang mendasari penyusunan instrumen bertolak dari indikatorindikator variabel penelitian yang diturunkan dari dimensi yang berlandaskan teori masing-masing variabel yang telah dibangun. Selanjutnya dari indikator atau kisikisi tersebut dijabarkan menjadi beberapa butir pernyataan, sesuai dengan kandungan makna yang terkandung dalam indikator tersebut.

\subsubsection{Kisi-Kisi Instrumen}

\subsubsection{Kepuasan kerja Guru $\left(\mathrm{X}_{3}\right)$}

Dari definisi konseptual yang telah diuraiakan di atas, maka dimensi variabel Kepuasan kerja guru adalah : (1) Kualitas hasil kerja, yaitu penilaian yang didasarkan pada kualitas output yang dicapai dan kualitas dalam melakukan pekerjaan; (2) Kuantitas hasil kerja yaitu penilaian yang dilakukan dengan membandingkan jumlah output yang dihasilkan dengan target yang telah ditetapkan; (3) Pengetahuan akan pekerjaan yaitu menunjukkan tingkat pengetahuan sesorang terhadap suatu pekerjaan atau hal-hal yang berhubungan dengan pekerjaan; (4) Kemampuan analitis yaitu karakteristik individu yang menggambarkan aktivitas mental seseorang dalam menghadapi suatu pekerjaan.; (5) Sikap terhadap orang lain yaitu penilaian yang dilakukan terhadap seseorang dalam hubungannya dengan orang lain terutama dalam membina hubungan kerja; dan (6) Tanggung jawab yang menunjukkan rasa tanggung jawab seseorang terhadap pelaksanaan tugas, sanggup menerima resiko atas keputusan dan tindakan yang diambilnya serta sanggup menjaga kepercayaan yang diberikan kepadanya.

Dari indikator-indikator tersebut dikembangkan menjadi butir instrumen sebanyak 30 butir instrumen. Penyebaran butir-butir instrumen disajikan sebagai berikut: 
Tabel 3.3 Kisi-kisi Instrumen variabel Kepuasan Kerja Guru

\begin{tabular}{|c|c|c|c|}
\hline Dimensi & Indikator & $\begin{array}{l}\text { Nomor } \\
\text { Butir }\end{array}$ & $\begin{array}{c}\text { Jumlah } \\
\text { Butir }\end{array}$ \\
\hline \multirow{3}{*}{$\begin{array}{l}\text { Pekerjaan } \\
\text { itu sendiri }\end{array}$} & $\begin{array}{l}\text { Pekerjaan sesuai dengan bidang } \\
\text { keahlian }\end{array}$ & 5,24 & 2 \\
\hline & $\begin{array}{l}\text { Berkesempatan untuk } \\
\text { menggunakan metode sendiri } \\
\text { dalam bertugas }\end{array}$ & 20 & 1 \\
\hline & $\begin{array}{l}\text { Pekerjaan tersebut memberikan } \\
\text { tantangan tersendiri }\end{array}$ & 18,29 & 2 \\
\hline \multirow[t]{3}{*}{ Gaji } & $\begin{array}{l}\text { Gaji yang diterima telah sesuai } \\
\text { dengan pekeriaan yang } \\
\text { dilakukan } 1\end{array}$ & 28,15 & 2 \\
\hline & $\begin{array}{l}\text { Gaji yang diterima sudah cukup } \\
\text { untuk memenuhi kebutuhan }\end{array}$ & 1,6 & 2 \\
\hline & $\begin{array}{l}\text { Besarnya tunjangan sudah sesuai } \\
\text { dengan tanggung jawab }\end{array}$ & 11 & 1 \\
\hline \multirow[t]{3}{*}{ Pengawasan } & $\begin{array}{l}\text { Pimpinan rutin melakukan } \\
\text { pengawasan }\end{array}$ & 13,26 & 2 \\
\hline & $\begin{array}{l}\text { Pimpinan memberikan pujian } \\
\text { terhadap hasil pekerjaan }\end{array}$ & $3,8,30$ & 3 \\
\hline & $\begin{array}{l}\text { Pimpinan telah menerapkan } \\
\text { aturan terhadap tenaga pengajar }\end{array}$ & 16,27 & 2 \\
\hline $\begin{array}{l}\text { Kesempatan } \\
\text { promosi }\end{array}$ & $\begin{array}{l}\text { Berkesempatan untuk melakukan } \\
\text { pengembangan diri dalam } \\
\text { organisasi }\end{array}$ & $7,10,21$ & 3 \\
\hline
\end{tabular}




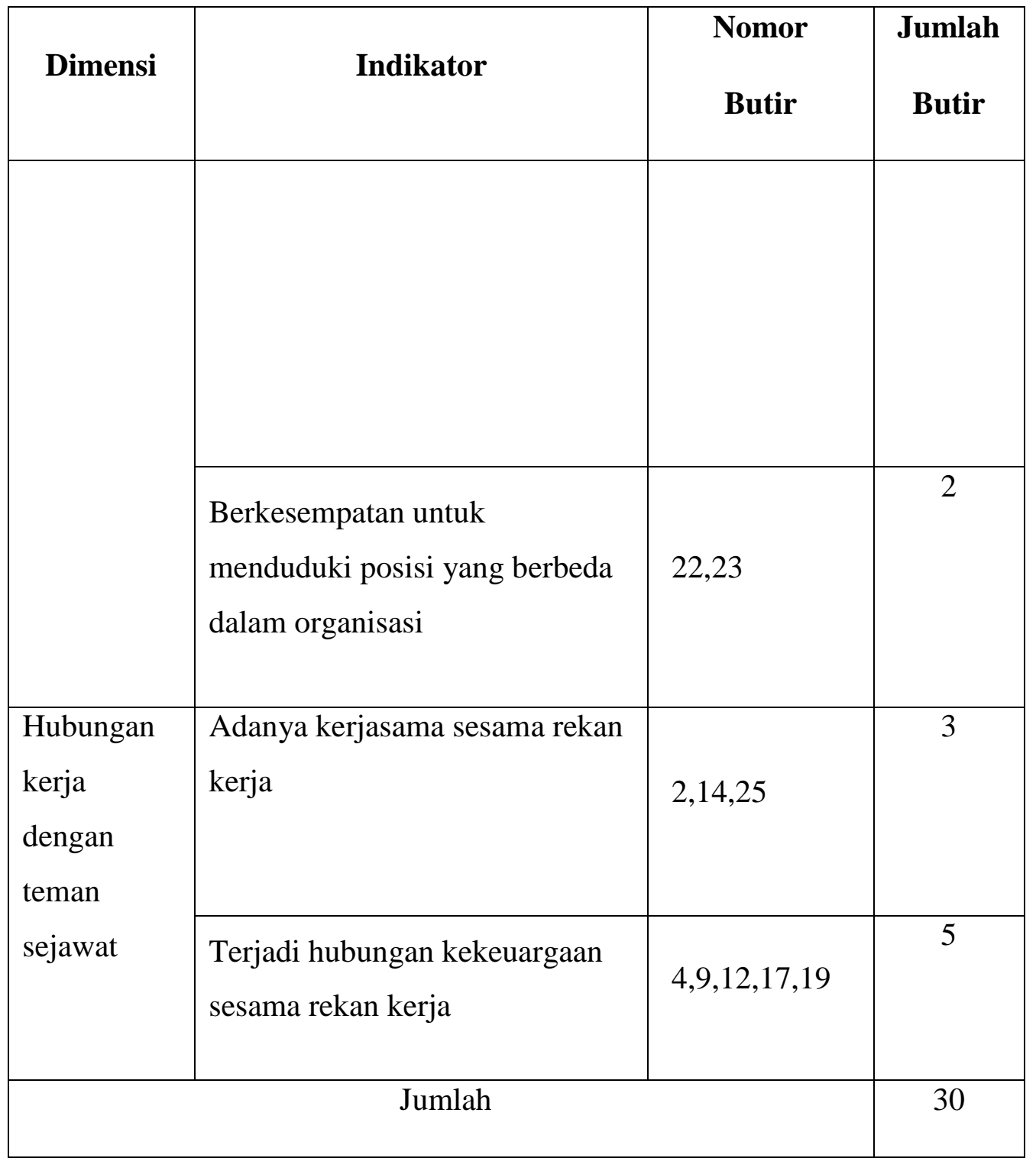

\subsubsection{Variabel Lingkungan Kerja Guru $\left(\mathrm{X}_{1}\right)$}

Dari definisi konseptual yang telah diuraikan di atas, maka dimensi variabel lingkungan kerja guru adalah : (1) Lingkungan fisik, yang meliputi indikator : ruang kerja, dan peralatan kerja; (2) Hubungan Kerja, meliputi indikator : komunikasi, kerjasama, suasana kerja, dan perilaku.

Dari indikator tersebut dikembangkan menjadi butir instrumen sebanyak 30 butir. Penyebaran butir tersebut dapat dilihat pada tabel berikut ini. 
Tabel 3.4 Kisi-kisi Instrumen Variabel Lingkungan Kerja Guru

\begin{tabular}{|c|l|l|c|}
\hline Dimensi & \multicolumn{1}{|c|}{ Indikator } & Nomor Butir & Jumlah \\
\hline $\begin{array}{c}\text { Kondisi } \\
\text { Tempat } \\
\text { Kerja }\end{array}$ & Penerangan & $7,8,9,10,11,21,22$, & 7 \\
\cline { 2 - 4 } & Kenyamanan & $5,6,12,15,23,24$, & 8 \\
& Sirkulasi udara & 27,29 & \\
\cline { 2 - 4 } & & $1,2,3,4$, & 7 \\
\hline \multirow{2}{*}{$\begin{array}{l}\text { Kubungan } \\
\text { Kerja }\end{array}$} & Komunikasi & $25,26,28$ & 2 \\
\cline { 2 - 4 } & Jaminan Kesehatan & 13,14 & 2 \\
\cline { 2 - 4 } & Kerjasama & $16,17,18,30$ & 30 \\
\hline
\end{tabular}

\subsubsection{Variabel Disiplin Kerja Guru $\left(\mathbf{X}_{3}\right)$}

Dari definisi konseptual yang telah diuraiakan di atas, maka dalam variabel disiplin kerja guru meliputi dimensi-dimensi beserta indikator-indikatornya adalah sebagai berikut : (1) Disiplin terhadap tugas kedinasan yang meliputi : mentaati peraturan kerja, menyiapkan kelengkapan mengajar, dan melaksanakan tugas-tugas pokok; (2) Disiplin terhadap waktu yang meliputi: menepati waktu tugas, memanfaatkan waktu dengan baik, dan menyelesaikan tugas tepat waktu; (3) Disiplin terhadap suasana kerja yang meliputi: memanfaatkan lingkungan sekolah, menjalin hubungan yang baik, dan menjaga keseimbangan antara hak dan kewajiban; (4) Disiplin di dalam melayani masyarakat yang meliputi: melayani peserta didik, melayani orang tua siswa, dan melayani masyarakat 
sekitar; dan (5) Disiplin terhadap sikap dan tingkah laku yang meliputi, memperhatikan sikap, memperhatikan tingkah laku, dan memperhatikan harga diri.

Dari indikator-indikator tersebut dikembangkan menjadi butir instrumen sebanyak 30 butir instrumen. Penyebaran butir-butir instrumen disajikan sebagai berikut:

Tabel 3.5 Kisi-Kisi Intrumen Variabel Disiplin Kerja Guru

\begin{tabular}{|c|c|c|c|}
\hline Dimensi & Indikator & $\begin{array}{l}\text { Nomor } \\
\text { Butir }\end{array}$ & $\begin{array}{c}\text { Jumlah } \\
\text { Butir }\end{array}$ \\
\hline \multirow{2}{*}{$\begin{array}{l}\text { Ketaatan } \\
\text { pada } \\
\text { peraturan }\end{array}$} & $\begin{array}{l}\text { 1. Mentaati peraturan } \\
\text { kerja. }\end{array}$ & $1,5,6,7,8,19$ & 6 \\
\hline & $\begin{array}{l}\text { 2. Menyiapkan } \\
\text { kelengkapan mengajar }\end{array}$ & $13,25,26,27$ & 4 \\
\hline \multirow{2}{*}{$\begin{array}{l}\text { Disiplin } \\
\text { terhadap } \\
\text { waktu }\end{array}$} & 1.Menepati waktu tugas. & $2,3,9,10$ & 4 \\
\hline & $\begin{array}{l}\text { 2.Menyelesaikan tugas } \\
\text { tepat waktu }\end{array}$ & $4,11,20$ & 3 \\
\hline \multirow{3}{*}{$\begin{array}{c}\text { Tanggung } \\
\text { jawab }\end{array}$} & $\begin{array}{l}\text { 1.Menggunakan fasilitas } \\
\text { sekolah dengan baik. }\end{array}$ & $12,14,28,29,30$ & 5 \\
\hline & $\begin{array}{l}\text { 2.Evaluasi diri terhadap } \\
\text { tugas yang diberikan }\end{array}$ & $21,22,23,24$ & 4 \\
\hline & $\begin{array}{l}\text { 3. Menghasilkan } \\
\text { pekerjaan yang baik }\end{array}$ & $15,16,17,18$ & 4 \\
\hline \multicolumn{3}{|c|}{ Jumlah } & 30 \\
\hline
\end{tabular}




\subsection{Uji Validitas dan Reliabilitas Instrumen}

Menurut Ruseffendi, menyatakan, bahwa suatu instrumen dikatakan memenuhi persyaratan yang baik apabila hasil uji validitas dan uji reliabilitas adalah tinggi ( E.T.Ruseffendi, 2003:132).

\subsubsection{Uji Validitas}

Santosa, P. B. dan Ashari mengemukakan, bahwa validitas adalah ukuran yang menunjukkan sejauhmana instrumen pengukur mampu mengukur apa yang ingin diukur ( Santosa,2005:251). Terdapat beberapa jenis validitas :

(1). Validitas Konstruksi. Suatu kuesioner yang baik harus dapat mengukur dengan jelas kerangka dari penelitian yang akan dilakukan. Jadi misalkan kita akan mengukur konsep tentang disiplin guru, maka kuesioner tersebut dikatakan valid jika mampu menjelaskan dan mengukur kerangka konsep disiplin guru.

(2) Validitas Isi. Validitas Isi adalah suatu alat yang mengukur sejauhmana kuesioner atau alat ukur tersebut mewakili semua aspek yang dianggap sebagai kerangka konsep.

(3) Validitas Prediktif. Validitas prediktif adalah kemampuan dari kuesioner dalam memprediksi perilaku dari konsep.

Untuk melakukan uji validitas, metode yang digunakan adalah dengan mengukur korelasi antara butir-butir pernyataan dengan skor pertanyaan secara keseluruhan. Tahap-tahap yang harus dilakukan untuk melakukan pengujian validitas adalah : (1). Mendefinisikan secara operasional suatu konsep atau variabel yang akan diukur. Jadi untuk menguji validitas suatu konsep atau variabel, tahap awal yang harus dilakukan adalah menjabarkan konsep dalam suatu definisi oerasional; (2) Melakukan uji coba pada beberapa responden. Uji coba minimal dilakukan terhadap 30 orang; (3) Mempersiapkan tabel tabulasi jawaban responden. (4) Menghitung nilai korelasi antara masing-masing skor butir jawaban dengan skor total dari butir jawaban. (5) Kesimpulan, bahwa suatu butir pernyataan dikatakan valid bila $\mathrm{r}$ hitung $<\mathrm{r}$ tabel kritis. 
Valid tidaknya butir soal ditentukan oleh perbandingan $r_{\text {hitung }}$ dengan $r_{\text {tabel }}$. Jika $r_{h i t u n g}>r_{\text {tabel}}$, maka butir soal tersebut dinyatakan valid sebaliknya jika $r_{h i t u n g}$ $<\mathrm{r}_{\text {tabel}}$, maka butir soal dinyatakan tidak valid.

\subsubsection{Uji Reliabilitas}

Bila suatu alat pengukuran telah dinyatakan valid, maka tahap berikutnya adalah mengukur reliabilitas dari instrumen. Reliabilitas adalah ukuran yang menunjukkan konsistensi dari alat ukur dalam mengukur gejala yang sama di lain kesempatan. Misalkan pada penelitian ini, penulis akan mengukur salah satu variabelnya adalah disiplin guru, maka hasil kuesioner tersebut akan sama jika digunakan untuk mengukur disiplin siswa pada penelitian di waktu yang lain Santosa, P. B. dan Ashari. Pengukuran reliabilitas dilakukan dengan dua cara, yaitu :

Repeated Measure atau pengukuran berulang. Di sini pengukuran dilakukan berulang-ulang pada waktu yang berbeda, dengan kuesioner atau pernyataan yang sama. Hasil pengukuran dilihat apakah konsisten dengan pengukuran sebelumnya.

One Shot. Pada teknik ini pengukuran dilakukan hanya pada satu waktu, kemudian dilakukan perbandingan dengan pernyataan yang lain atau dengan pengukuran korelasi antar jawaban. Pada program SPSS, metode ini dilakukan dengan metode Cronbach Alpha, di mana suatu kuesioner dikatakan reliabel jika nilai cronbach Alpha lebih besar minimal 0,60 ( Santosa, 2005:251).

Jika Hasil perhitungan ternyata $r_{11}>0,44$ maka dianggap reliabel (ajeg) jika $\mathrm{r}_{11}<0,44$ maka instrumen dianggap tidak reliabel, sehingga instrumen tidak dapat digunakan untuk penelitian.

\subsection{Teknik Analisis Data}

Dari data yang terkumpul dianalisis dengan menggunakan statistik deskriptif dan inferensial yang sering disebut statistik probabilitas. Dari statistik deskriptif untuk mengukur dan penyajian ukuran gejala terpusat yang terdiri dari skor 
minimum dan maksimum. Analisis statistik deskriptif dilakukan dengan mendeskripsikan semua data dari semua variabel dalam bentuk distribusi frekuensi, histigram, modus, median, dan validitas, reliabilitas, atau penyebaran rentang skor dan simpangan baku. Sedangkan analisis statistik inferensial adalah teknik statistik yang digunakan untuk menguji hipotesis yang akan memakai analisis jalur (path analisis).

Uji persyaratan analisis yang digunakan dalam penelitian ini terdiri dari :

1. Uji normalitas data

Uji ini dimaksudkan untuk menentukan normal atau tidaknya distribus data penelitian dengan menggunakan uji Liliefors (data dikatakan normal bila $\mathrm{L}_{\text {hitung }}$ $<\mathrm{L}_{\text {tabel }}$ diuji pada taraf signifikan $\alpha=0,05$.

2. Uji homogenitas data.

Uji ini dimaksudkan untuk menguji kesamaan dua buah varians populasi yang berdistribusi normal. Uji homogenitas data dengan menggunakan uji Bartlett. Data dikatakan homogen apabila $X_{\text {hitung }}<X_{\text {tabel }}$ diuji pada taraf signifikan $\alpha=0,05$.

\section{Uji Linieritas Data dan Keberartian Regresi}

Uji linieritas regresi dan keberartian regresi dari persamaan regresi linier sederhana antara $X_{1}$ dan $X_{3}, X_{2}$ dan $X_{3}$, serta $X_{1}$ dan $X_{2}$ digunakan analisis varians melalui tabel ANAVA. Dengan ketentuan apabila pada baris Tuna Cocok dihasilkan $F_{\text {hitung }}<\mathrm{F}_{\text {tabel, }}$, maka persamaan regresinya linier. Dan apabila pada baris regresi (b/a) dihasilkan $F_{\text {hitung }}>F_{\text {tabel, }}$ maka koefisien regresinya dikatakan berarti.

4. Pengujian Hipotesis Statistik

Berdasarkan pengajuan hipotesis, konstelasi variabel, dan teknik analisis data tersebut maka dapat disusun hipotesis statistik sebagai berikut :

Hipotesis 1

$\mathrm{H}_{0}: \mathrm{P}_{31} \leq 0$ 
$\mathrm{H}_{1}: \mathrm{P}_{31}>0$

Hipotesis 2

$\mathrm{H}_{0}: \mathrm{P}_{32} \leq 0$

$\mathrm{H}_{1}: \mathrm{P}_{32}>0$

Hipotesis 3

$\mathrm{H}_{0}: \mathrm{P}_{21} \leq 0$

$\mathrm{H}_{1}: \mathrm{P}_{21}>0$

Keterangan :

$\mathrm{H}_{0}=$ Hipotesis nol

$\mathrm{H}_{1}=$ Hipotesis Penelitian

$\mathrm{P}_{31}=$ Koefisien pengaruh kepuasan kerja terhadap lingkungan kerja

$\mathrm{P}_{32}=$ Koefisien pengaruh kepuasan kerja terhadap disiplin kerja

$\mathrm{P}_{21}=$ Koefisien pengaruh lingkungan kerja terhadap disiplin kerja

\section{SIMPULAN DAN SARAN}

\subsection{Simpulan}

Penelitian mengenai pengaruh lingkungan kerja dan disiplin kerja guru terhadap kepuasan kerj guru SMK di kecamatan Pondok Aren telah mengikuti tahapan-tahapan yang merupakan suatu aturan yang lazim di dalam pelaksanaan penelitian, yaitu pembuatan proposal, pembuatan instrumen penelitian, melakukan uji coba instrumen, melaksanakan pengumpulan data, menganalisis data dan penarikan kesimpulan.

Berdasarkan hasil analisis dan pembahasan, maka dapat ditarik kesimpulan sebagai berikut :

1) Hasil pengujian hipotesis pertama yang menyatakan bahwa terdapat pengaruh positif Lingkungan Kerja Guru terhadap Kepuasan Kerja Guru 
SMK di kecamatan Pondok Aren, berdasarkan hasil uji signifikansi dan linieritas persamaan regresi dalam persamaan $\mathrm{X}_{3}=8,49+0,95 \mathrm{X}_{2}$, ternyata signifikan dan linier, yaitu berarti bahwa setiap kenaikan 1 skor kepuasan kerja guru dipengaruhi oleh kenaikan skor 0,95 kali skor disiplin kerja guru pada titik konstanta 8,49. Tingkat kekuatan pengaruh disiplin kerja terhadap kepuasan kerja guru dapat ditunjukan dari koefisien korelasi 0,351. Matriks koefisien korelasi dalam analisis jalur disiplin kerja terhadap kepuasan kerja guru memperoleh $\mathrm{p}_{32}=0,08>0,05$ berarti $\mathrm{p}_{31}$ signifikan pada koefisien korelasi 0,351 hal ini berarti hipotesis 1 teruji, artinya bahwa semakin baik lingkungan kerja guru maka semakin baik pula kepuasan kerja guru. Koefisien determinasi sebesar 0,1232 menerangkan bahwa 12,32 \% variansi variabel Kepuasan Kerja Guru dijelaskan/ditentukan oleh variabel Lingkungan Kerja.

2) Hasil pengujian hipotesis kedua yang menyatakan bahwa terdapat pengaruh positif Disiplin Kerja Guru terhadap Kepuasan Kerja Guru SMK di kecamatan Pondok Aren, berdasarkan hasil uji signifikansi dan linieritas persamaan regresi dalam persamaan $X_{3}=45,92+0,59 X_{1}$, ternyata signifikan dan linier, yaitu berarti bahwa setiap kenaikan 1 skor kepuasan kerja guru dipengaruhi oleh kenaikan skor 0,59 kali skor lingkungan kerja guru pada titik konstanta 45,92. Tingkat kekuatan pengaruh lingkungan kerja terhadap kepuasan kerja guru dapat ditunjukan dari koefisien korelasi 0,351. Matriks koefisien korelasi dalam analisis jalur disiplin kerja terhadap kepuasan kerja guru memperoleh $\mathrm{p}_{32}=0,43>0,05$ berarti $\mathrm{p}_{32}$ signifikan pada koefisien korelasi 0,351 hal ini berarti hipotesis 1 teruji, artinya bahwa semakin baik disiplin kerja guru maka semakin baik pula kepuasan kerja guru. Koefisien determinasi sebesar 0,308 menerangkan bahwa 30,80\% variansi variabel Kepuasan Kerja Guru dijelaskan/ditentukan oleh variabel Disiplin Kerja.

3) Hasil pengujian hipotesis ketiga yang menyatakan bahwa terdapat pengaruh positif Lingkungan Kerja Guru terhadap Disiplin Kerja Guru SMK di kecamatan Pondok Aren, berdasarkan hasil uji signifikansi dan linieritas persamaan regresi dalam persamaan $\mathrm{X}_{2}=37,42+0,64 \mathrm{X}_{1}$, ternyata signifikan dan linier, yaitu berarti bahwa setiap kenaikan 1 skor disiplin kerja guru 
dipengaruhi oleh kenaikan skor 0,64 kali skor lingkungan kerja guru pada titik konstanta 37,42. Tingkat kekuatan pengaruh lingkungan kerja terhadap disiplin kerja guru dapat ditunjukan dari koefisien korelasi 0,514. Matriks koefisien korelasi dalam analisis jalur lingkungan kerja terhadap kepuasan kerja guru memperoleh $\mathrm{p}_{21}=0,51>0,05$ berarti $\mathrm{p}_{21}$ signifikan pada koefisien korelasi 0,514 hal ini berarti hipotesis 1 teruji, artinya bahwa semakin baik lingkungan kerja guru maka semakin baik pula disiplin kerja guru. Koefisien determinasi sebesar 0,2641 menerengkan bahwa 26,41\% variansi variabel Disiplin Kerja Guru dijelaskan/ditentukan oleh variabel Lingkungan Kerja.

\subsection{Saran}

Berdasarakan kesimpulan hasil penelitian dan implikasinya, maka dapat dikemukakan saran-saran antara lain sebagaia berikut:

1. Lingkungan sekolah hendaknya menjadi rumah kedua bagi seorang guru, sehingga dapat meningkatkan kepuasan kerja guru yang akan berdampak tehadap meningkatkan kualitas diri, baik sikap maupun akademik. Oleh karena itu hendaknya lingkungan sekolah dibuat bersih, kondusif, sarana dan prasarana memadai dan sebagaianya.

2. Kepala sekolah dalam menegakkan kedisiplinan hendaknya bersikap fleksibel sesuai dengan situasi dan kondisi yang dihadapi, terutama dalam pengambilan keputusan.

3. Guru hendaknya dapat membina hubungan yang harmonis antar sesama guru, dan dengan kepala sekolah sehinga dapat meningkatkan kedisiplinan kerja guru dalam melaksanakan tugasnya. 
4. Guru hendaknya dapat memberi masukan dan respon positif terhadap berbagai permasalahan yang terjadi di seklah, membantu memberikan jalan keluar yang terbaik demi kemajuan sekolah.

\section{DAFTAR PUSTAKA}

Anoraga, Pandji. 2006. Psikologi Kerj a. Jakarta: PT Rineka Cipta.As'ad, Moh. 1995. Psikologi Industri. Yogyakarta : Liberty.

Asnawi, S. 1999. Manajemen Sumber Daya Manusia. Jakarta : Rajawali Press.

Baron, James N., Byne. 1999. Strategic Human Resources-Frameworks for

General Manager. (New York: John Wiley \& Sons, Inc.

Bernardin, H. Jhon dan Russel, Joyce E.A. 1998. Human Resource Management: An Experential Approach. Boston : McGraw-Hill.

Byars, Lloyd L., dan Rue, Leslie W. 2000. Human Resource Management. Edisi Terjemahan. Boston: McGraw-Hill.

Candra S. 2007. Pengaruh Loyalitas dan Lingkungan Kerja Terhadap Motivasi Kerja Guru SMP Negeri Di Kecamatan Warung Kiara Kabupaten Sukabumi Jawa Barat. (Tidak dipublikasikan).

Davis, Keith \& William B. Werther, Jr. 1996. Human Resource and Personnel Management, Edisi Terjemahan, Jakarta: Prenhallindo.

Dharma, Agus. 2004. Manajemen Prestasi Kerja. Jakarta : Rajawali Press.

Fadila, Avin H. 1996. Disiplin Kerja. Buletin Psikologi, Tahun IV No.2 Desember. 
Ghofar, Abdul S. A. S. Pengaruh Strategi Manufaktur Terhadap Kinerja. Jurnal Manajemen Maranatha Volume 3, Mei 2004

Ghozali, I. 2007. Aplikasi Analisis Multivariate dengan Program SPSS. Cetakan Keempat. Semarang: Badan Penerbit Universitas Diponegoro.

Hasibuan, Malayu S.P. 1997. Manajemen sumber daya manusia. Jakarta: Gunung Agung.

2000. Manajemen Sumberdaya Manusia : Dasar dan Kunci. Jakarta

: Gunung Agung.

Heidjrachman dan Suad Husnan. 2000. Manajemen Personalia, Edisi 4, Cetakan ke Sembilan. Yogyakarta: BPFE.

Jasin, A. 1989. Peningkatan Pembinaan Disiplin Nasional Dalam Sistem dan Pola Pendidikan Nasional. Dalam Analisis CSIS. No.4 Tahun XVII, Juli-Agustus.

Keke T. Aritonang. 2005. Kompensasi Kerja, Disiplin Kerja Guru dan Kinerja Guru SMP Kristen BPK PENABUR Jakarta, Jurnal Pendidikan Penabur - No.04/ Th.IV / Jakarta: BPK Penabur, Juli.

Kuswadi. 2005. Cara Mengukur Kepuasan Karyawan. Jakarta: PT Elex Media Komputindo.

Mangkunegara, A.A. Anwar Prabu. 2001. Manajemen Sumber Daya Manusia Perusahaan. Bandung: PT. Remaja Rosdakarya.

Mangkunegara, Anwar Prabu. 2004. Manajemen Sumber Daya Manusia Perusahaan. Bandung: PT Remaja Rosdakarya. 
Moekijat. 2002. Tata Laksana Kantor. Bandung : Alumni.

Niti Seminto, S. Alex. 1992. Manajemen Personalia. Jakarta : Ghalia Indonesia.

Rivai, Veithzal. 2004. Manajemen Sumber Daya Manusia Untuk Perusahaan.

Jakarta: PT. Raja Grafindo Persada.

Ruseffendi, E. T. 2003. Dasar-dasar Penelitian Pendidikan dan Bidang Non-Eksakta Lainnya. Jakarta: Unnes Press.

Santosa, P. B. dan Ashari. 2005. Analisis Statistik dengan Microsoft Excel dan SPSS. Yogyakarta: ANDI.

Sedarmayanti. 2001. Sumber Daya Manusia dan Produktivitas Kerja.

Bandung:C.V Mandar Maju.

Shochib. M. 2001. Pola Asuh Orang Tua; Untuk Membantu Anak Mengembangkan Disiplin Diri. Jakarta: Rineka Cipta.

Siagian, Sondang P. 2006. Manajemen Sumber Daya Manusia. Jakarta: PT Bumi Aksara.

Simamora, Henry. 1999. Manajemen Sumber Daya Manusia; Edisi Kedua. Yogyakarta: STIE YKPN.

Sugiyono. 2002. Statistik untuk Penelitian. Bandung: Alfabeta

Sukardi. 2003. Metodologi Penelitian Pendidikan; Kompetensi dan Praktiknya. Jakarta: PT. Bumi Aksara.

Sukmalana, S. 2008. Metode dan Teknik Penulisan Karya Ilmiah. Jakarta: Univ. Suryadharma.

The Liang Gie. 1992. Efisiensi Kerja Bagi Pembangunan Negara. Jakarta : Erlangga. 
Widodo, 2004, Cerdik Menyusun Proposal Penelitian Skripsi, Tesis dan Disertasi, Jakarta: Magna Script. 